\title{
Nutrient-Rich Beans with Benefit (Vigna radiata (L.) Wilczek): A Review
}

\author{
Jyoti Prakash Sahoo $^{1 *}$, Ambika Prasad Mishra ${ }^{2}$, Deviprasad Mishra ${ }^{1}$ \\ and Kailash Chandra Samal ${ }^{1}$
}

${ }^{1}$ Department of Agricultural Biotechnology, ${ }^{2}$ Department of Soil Science and Agricultural Chemistry, Odisha University of Agriculture and Technology, BBSR -751003, India

*Corresponding author

\section{Ke y w o r d s \\ Mungbean, \\ Genetics, Molecular marker, QTLs, Crop improvement}

Article Info

Accepted:

24 July 2020

Available Online:

10 August 2020

\section{A B S T R A C T}

Mung bean (Vigna radiata (L.) Wilczek), commonly known as greengram, is a significant grain legume crop cultivated across the globe and is native to India. It is the most useful pulse crop having an economic significance towards the nutritional security and sustainable agriculture. As it is rich in vitamins, minerals and proteins which are easily digestible, it is an inseparable ingredient in Indian diet when supplemented with cereals particularly rice. It assimilates the atmospheric nitrogen with the Rhizobium bacterial symbiotic association. It subsequently provides the requirement of nitrogen for itself and the next crop in that particular land. It is a short duration crop and due to its photo and thermo insensitive characteristics, it is generally used for crop diversification and crop intensification purposes. A seed of mungbean is highly nutritious for human consumption. It contains edible proteins, fats, fibers and carbohydrates. Mungbean is a tropical legume widely cultivate in the subtropical climatic conditions across the globe. It can tolerate dry land condition for cultivation and decrease the depletion of soil nutrient status. It is constantly used as a fodder crop and a green manuring crop since decades. This review aims to highlight the importance of greengram as a crop in the context of food security, improvement of its agronomic characters and the progress on the recent research and development to explore its genetics using recent developed biotechnological tools.

\section{Introduction}

Mungbean (Vigna radiata $\mathrm{L}$. Wilczek) is one of the economically important pulse crops. It belongs to the subgenus Ceratotropis and is having a diploid genome with $2 \mathrm{n}=22$. This crop is of minor importance with constrained spatial distribution and has watchfully been employed in cytogenetic experiments. On account of quality protein and minerals contain, this crop is commonly taken as a balanced diet in India. Precisely when improved with oats, they give a perfect mix of essential amino acids with high biological importance. In symbiotic association with Rhizobium, mungbean can assimilate atmospheric nitrogen and enables the criteria to meet the essential nitrogen requirement of its own along with the succeeding crops (Ali, 1992). In India, when it is grown between 
wheat and rice precisely, it gives around 33 $37 \mathrm{~kg}$ nitrogen $(\mathrm{N})$ per hectare for the succeeding crop. It has also been reported that, these crops have a smooth weed flora of $(20-45 \%)$ when used as an intercrop with tall cereal crops (Ali, 1992) and consequently sustain the cost of weed control.

On dry weight basis, the highly nutritious seeds of mungbean contain around $24-28 \%$ easily digestable protein, around $1.5 \%$ fat content, 3.5-4.5\% fibre content, $4.5-5.5 \%$ ash content and 59-65\% carbohydrates content (Tsou et al., 1979). Mungben seeds provide 334-344 kcal energy when supplemented with rice (Mehandi et al., 2019). The haulms of mungbean are traditionally used for fodder. The beans and husks of the mungbean have a great utility for cattle feed purposes. Also the greengram crops are cultivated for hay, green manure and cover crop purposes. As the stems and leaves of mungbean are comparatively less hairy, it yields better hay content than uradbean. In the present situation, for $95 \%$ of the caloric intake in the daily basis, the global food supply chain is based on thirty different food crops out of which $60 \%$ of the caloric intake in daily basis is supplemented by mostly four important crops i.e., rice, wheat, maize and potato including some minor crops. Across the globe in the context of mungbean production, only the continent Asia accounts for $90 \%$ with an average yield of about $400 \mathrm{~kg}$ per hectare (Mehandi et al., 2019).

To human diet, mungbean supplies necessarily significant amount of carbohydrates and proteins as it contains lysine which is an essential amino acid generally lacking in cereals. Though it is having a poor quantity of methionine, the beans contain the high level of free radical activity (Mehandi et al., 2019). Sprouts of mungbean are the rich source of vitamins and minerals. The production time of the sprouts is less and these are generally marketed as fresh sprouts or in processed form. Mungbean production increases the income of the farmer through the sale of the beans either in fresh or processed form. The cultivation of the mungbean also reduces the farm inputs after cultivation (Mehandi et al., 2019). In many relevant cases, these minor crops like greengram are grown for staple food purposes, contributing to the global food supply. Therefore, this review aims to outline the status on mungbean towards the resistance breeding for the biotic and abiotic stresses to increase its yield and its potential contribution towards the global food security that could increase farmer's income.

\section{Origin and ecology}

The mungbean is native to north eastern India. According to the morphological evidence, researchers have considered that, var. sublobata is the progenitor of mungbean. The detailed studies on wide collections of var. sublobata and its breeding behavior suggested that the var. sublobata is a polymorphic taxon with two distinct morphological groups and can be designated as Vigna radiata var. sublobata (Rachie et al., 1974). The wild collections have characteristics like annual growth habit, erect plant type, photoperiod insensitivity, more pods with high number of seeds, and smaller leaves. The present day cultivars of mungbean might have emerged from new combinations of the already existing variants, changes in growth habit and seed size have been brought about by possible accumulation of recessive mutant genes. Mungbean is a tropical grain legume crop typically cultivated in the subtropical countries. This legume performs excellent in loamy soils with an annual rainfall of about $750-900 \mathrm{~mm}$. It is resistant to drought and susceptible to water logging. It is grown in kharif, winter and summer seasons in different agro-ecological conditions. It is a 
very useful intercrop during the cultivation of crops like sugarcane, maize, cotton, groundnut, sorghum and pigeonpea during kharif season. While during winter season, it is cultivated as a relay crop with the cereal crop particularly rice and cultivated as a catch crop during summer season or spring season.

\section{Historical frame of reference}

In 1948, a promising variety, Type 1, was released to cultivate in UP and it was a locally selected germplasm from Bihar. During the period from 1948 to1970, some important varieties of mungbean, Co 1, ADT 1, Jalgaon, Khargone 1, Krishna, G 65 were developed for cultivation through selection procedure. In 1972, Jawahar 45 (Hybrid 45) was released for cultivation in Madhya Pradesh and in 1972, Type 44 was released for cultivation in Uttar Pradesh. Probably, these two varieties were the first two varieties developed through hybridization. A variety named Virat was released by ICAR-IIPR, Kanpur with 55 days of maturity characteristics. It is recommended for rice-wheat cropping system. Type 1 has been used afterward as one of the parents in hybridization programmes for the development of improved varieties like Type 2, K 851, T 44 and Sunaina. Utilization of $\mathrm{T}$ 44 in hybridization has resulted in the development of Pusa Baisakhi which, in turn, has given PIMS 4 and Jyoti. Through mutation breeding procedure, about 14 varieties have been developed using gamma rays or EMS (Ethyl Methane Sulphonate) as mutagens and the varieties developed through mutation are $\mathrm{CO} 4$, Pant Moong 2, TAP 7, BM 4, MUM 2 and TARM 1(Mehandi et al., 2019).

\section{Production constraints and research needs}

The significant limitations in the way to accomplish high return are absence of reasonable hereditary changeability, nonappearance of commendable ideotypes for different cropping system and cropping patterns, biotic and abiotic stress susceptibility and non-accessibility of viable seeds. The significant yield restricting variables are seedling vigour, excessive flower production, flower drops, poor pod setting, poor harvest index, monocarpic senescence, low response to inputs, narrow adaptation, indeterminate growth habit, staggered maturity and sensitivity to photoperiods and temperature.

During kharif season, mungbean yellow mosaic infection (MYMV) and during spring season cercospora leaf spot disease caused by C. canescens are the significant disease infections which cause severe yield loss to mungbean. During the vegetative stage, defoliation coours and the defoliators like semi-looper and hairy caterpillar are the important pests which cause yield loss. Action of thrips begins at the bud stage and postures difficult issues when the yield accomplishes top blossoming, bringing about substantial bloom drop. There is no resistant variety against these insect pests.

Varieties developed in the past with resistance to single stress may not be a viable solution as new diseases and insect pests are emerging leading towards pest resurgence. Therefore, varieties having resistance to more than one stress provide greater crop insurance towards the biotic stresses.

For mungbean, high yielding cultivars with crop duration of 85-90 days for kharif season and 65-70 days for spring season with decreased photoperiod affectability are required. For summer season, early varieties of 55-60 days are suitable for cultivation. In recent practice, large seeded varieties like Pusa Vishal, SML 668, TMV 37, and so forth have been created which have extraordinary market value. 


\section{Qualitative trait genetics and mapping of genes or QTLS}

Information on the genetics of some unusual traits in a crop is crucial to design its breeding programmes. Qualitative traits are responsible for the major agronomic characters which directly impact on the yield parameters. Several studies have been conducted to know the genetics of qualitative traits of greengram, which are presented in Table 1. Genetic diversity assessment utilizing the random RAPD markers shows close relatedness and similarity among mungbean accessions. The investigation uncovers restricted narrow genetic hereditary base of Indian cultivars presumably due the repeated use of limited ancestors in their pedigrees. This perception has additionally been affirmed utilizing RAPD (Betal et al., 2004; Afzal et al., 2004) and ISSR (Sinha et al., 2004; Saini et al., 2004) markers.

AFLP markers have additionally been utilized in mungbean to investigate the genetic diversity of mungbean germplasms (Ghat et al., 2005). The long primers yielded altogether higher number of discrete and recognizable groups just as polymorphic groups than 10-base primers. The outcomes show that long primers can be utilized proficiently for breaking down hereditary decent variety and the connections in mungbean germplasm. Expanding the seed weight has been one of the significant goals to grow high yielding assortments. RFLP markers are used to find major QTLs for the seed weight in mungbean (Mehandi et al., 2019). Studies on the hereditary connection between hard seededness and seed weight, be that as it may, are not indisputable. QTL mapping approach (Table 2) utilizing molecular markers have been utilized to examine the linkage connection between some genes or QTLs with remarkable traits having economic importance towards greengram cultivation and achieving a good yield.

\section{Breeding approaches and crop improvement strategies}

The breeding strategies to develop disease resistance high yielding greengram varieties are generally included the traditional breeding methods like wide hybridization, pedigree selection, pureline selection and mutation breeding strategies. Major emphasis should be given to the short durability, photo-thermo insensitivity, synchronous maturity and MYMV (mungbean yellow mosaic virus), powdery mildew disease and CLS (Cercospora leaf spot) resistance while experimenting on selection procedure. More than 150 accessions have been developed so far in India by employing pure line selection procedure and pedigree selection followed by hybridization (Mehandi et al., 2019). Mungbean is adapted to tropical and subtropical lowlands for extensive cultivation.

It is relatively tolerant to abiotic stresses, like drought and heat stress but its productivity is affected by soil salinity. Along with the greengram plants in the field in standing condition, soil salinity interferes with symbiotic microorganisms associations such as Rhizobium sp. which is essential for biological nitrogen fixation resulting growth and yield reduction (Wati et al., 2017). Salt tolerant mungbean crop species, such as V. marina (sustain in highly saline conditions) may not be suitable to cross with mungbean due to which these are not available for breeding for salt tolerant varieties development (Chankaew et al., 2014). Mungbean yellow mosaic disease is one of the most important growth limiting biotic factor in mungbean cultivation. Against yellow mosaic virus disease, moderate resistance has been found in the genepools of mungbean, but this is not sufficient enough to explore resistant varieties. 
Table.1 Genetics of qualitative traits in greengram

\begin{tabular}{|c|c|c|c|}
\hline Traits & Characteristic features & Genes involved & Reference \\
\hline Growth habit & $\begin{array}{l}\text { Indeterminate, Erect, semi-erect, semi- } \\
\text { spreading or twining type }\end{array}$ & Single dominant or dwarf mutant gene involved & $\begin{array}{l}\text { Siddique et al.,2006, Khattak et } \\
\text { al.,2002, Pathak et al.,1963, Pande et } \\
\text { al.,1988, Talukdar } \text { et al., } 2003\end{array}$ \\
\hline Pigmentation & $\begin{array}{l}\text { Anthocyanin and purple pigmentation in } \\
\text { hypocotyl, epicotyl, stem and petiole }\end{array}$ & Single dominant genes (Pppl) involved & $\begin{array}{l}\text { Pathak et al., 1963, Rheenen et al., } \\
\text { 1965, Mishra et al., 1970, Dwivedi } \\
\text { et al., } 1985\end{array}$ \\
\hline Leaf size & $\begin{array}{l}\text { Pentafoliate, Ninefoliate, Narrow } \\
\text { lanceolate leaf, Trilobite leaf }\end{array}$ & $\begin{array}{l}\text { Single recessive, } 2 \text { recessive gene (nil, } \mathrm{n} 12), 2 \\
\text { dominant gene (Tibl and } \mathrm{T} 1 \mathrm{~b} 2 \text { ) involved }\end{array}$ & $\begin{array}{l}\text { Dwivedi et al., 1985, Chhabra et al., } \\
\text { 1990, Bhadra et al., 1991, Sareen } \text { et } \\
\text { al., } 1985\end{array}$ \\
\hline Stem fasciation & Stem fasciations on floral organs & Single recessive gene (fsl) involved & Dwivedi et al., 1990 \\
\hline Infloroscence & Number of clusters per node & Single dominant gene involved & Singh et al., 1995, Saini et al., 1974 \\
\hline Flower colour & Petal colour (red, yellow, olive yellow) & Single dominant gene involved & Bose et al., 1939, Murty et al., 1972 \\
\hline Pubescence & Dense plant pubescence & Single dominant gene $(\mathrm{Dp})$ involved & Murty et al., 1972 \\
\hline Pod colour & Black or brown mature pod & Single dominant gene involved & Siddique et al., 2006 \\
\hline Pod shattering & Dominant & Single gene involved & Singh et al., 1975 \\
\hline Seed coat colour & Black, brown, green and yellow & 4 genes involved (Two Complementary) & Watt et al., 1977, Mehandi et al., 2013 \\
\hline Seed coat & Dull and rough & Single dominant gene involved & Siddique et al., 2006 \\
\hline Cotyledon & Green colour & Single recessive gene $(\mathrm{gc})$ involved & Thakare et al., 1980 \\
\hline Seededness & Hard seededness & Single dominant gene (Hdl) involved & Lambrides et al., 1996 \\
\hline Photoperiod & Insensitive response & Single recessive gene involved & Verma et al., 1971 \\
\hline
\end{tabular}


Table.2 Genes or QTLs mapped for some remarkable traits in greengram

\begin{tabular}{|l|l|l|l|}
\hline Trait & Marker & Genes or QTLs and map distance & Reference \\
\hline Seed weight & RFLP & $\begin{array}{l}\text { Identification of a Major QTL, association } \\
\text { between seed weight and hard seededness } \\
\text { (Mapping Population } \text { F }_{2} \text { ), 4 loci for hard } \\
\text { seededness }\end{array}$ & $\begin{array}{l}\text { Lambrides } \text { et al., } \\
\text { 1996, Fatokun } \text { et } \\
\text { al., 1992, } \\
\text { Humphry } \text { et al., } \\
\text { 2005 }\end{array}$ \\
\hline CLS resistance & SSR & $\begin{array}{l}\text { First time QTL mapping for CLS } \\
\text { resistance in mungbean (qCLS) located } \\
\text { between markers CEDG117 and VR393 }\end{array}$ & $\begin{array}{l}\text { Sompong } \text { et al., } \\
2010\end{array}$ \\
\hline PW resistance & RFLP & $\begin{array}{l}\text { Genes, '13 m' and 'Thiz2' identified in a } \\
\text { cross population VC3890 } \times \text { TC1966 and } \\
\text { Identification of Two QTLs, '13MR1' } \\
\text { and 'PMR2' }\end{array}$ & $\begin{array}{l}\text { Sahli } \text { et al., 1979, } \\
\text { Chaitieng } \text { et al., } \\
2003\end{array}$ \\
\hline Bruchids resistance & SNP & Major resistance QTL mapped on cr no. 5 & $\begin{array}{l}\text { Schafleitner } \text { et } \\
\text { al., 2016 }\end{array}$ \\
\hline Domestication purpose & SSR & Total map distance of 727.6 cM & $\begin{array}{l}\text { Isemura } \text { et al., } \\
\text { 2012 }\end{array}$ \\
\hline MYMV resistance & SNP & Total map distance 1291.7 cM & $\begin{array}{l}\text { Mathivathana } \text { et } \\
\text { al., 2019 }\end{array}$ \\
\hline
\end{tabular}

(RFLP - Restriction fragmented length polymorphism, SSR - Simple sequence repeats, SNP - Single nucleotide polymorphism, CLS - Cercospora leaf spot, MYMV - Mungbean yellow mosaic virus, QTLs - Quantitative trait locus, cM - Centmorgan, PW - Powdery mildew, cr no. - chromosome number)

Studies suggested that, mutation breeding in mungbean resulted a certain significant level of resistance against yellow mosaic disease using the hybrids accessions and moderately resistant accessions of mungbean (Ashraf et al., 2001).

The resistance line NM94 (derived from mutation breeding) is now registered for yellow mosaic disease and now recommended for cultivation because of its high yielding criteria. ML1628, a variety which is found resistance to multiple strains of the virus causing MYMD, was released from Punjab Agricultural University (PAU), Ludhiana, India (Nair et al., 2017). Major store grain pests of mungbean like Bruchids (Callosobruchus sp.) lay their eggs on pods when the crop is in the standing condition in the field, which after hatching can destroy all stored mungbean grains (Lambrides et al., 2000) during storage. Marker-assisted selection (MAS) is a relevant aspect regarding mungbean breeding and now a days, genomewide association mapping is an important biotechnological tool to map the genes which are linked to some important agronomic traits. But, though mungbean is a minor crop, low funds inputs limit the population size for phenotypic analysis and ultimately result the mapping of simple oligogenic or monogenic traits. Examples of some important traits recently mapped in mungbean are tolerance to drought and high heat stress (Liu et al., 2017), development in seed starch content (Masariet $a l ., 2017)$, salinity tolerance (Chankaew et al., 2014), resistance to powdery mildew disease (Poolsawat et al., 2017), yellow mosaic virus disease(Singh et al., 2017), and bruchid resistance (Schafleitner et al., 2016, 
Kaewwongwal et al., 2017) which needs further validation experiments.

In conclusion, mungbean has the distinct benefit having a short crop duration. This truth in conjunction with its environmental nitrogen fixing capability makes it a vital source in numerous cereal-based cropping systems and cropping patterns. Proper evaluation is needed to establish a successful breeding strategy and utilization of germplasm assets from secondary and tertiary genepools by way of conventional and biotechnological tools for development of its agronomic traits. Incorporation of genes from its nearly related species for resistance or tolerance to biotic stresses like MYMV, bruchids and abiotic factors like sensitivity to photoperiods, high temperatures, drought, waterlogging, pre-harvest sprouting and nutrient use efficiency. Breeding for fixation of atmospheric nitrogen should be prioritized. The lack of development in salt tolerance of mungbean needs extra attention in the research. Knowledge gaps on breeding in opposition to economically critical pests and diseases have been addressed in the latest past. However, each issues want to be taken into consideration by way of countrywide breeding program followed with novel breeding approaches. Additionally, extra emphasis is required on exploring mungbean to combat hidden starvation by linking it to national food policies.

\section{Conflicts of interest}

All authors declare there is no conflict of interest among them.

\section{References}

Afzal MA, Hague MM, Shanmugasundaram S. Random amplified polymorphic DNA (RAPD) analysis of selected mungbean (Vigna radiate (L.) Wilczek) cultivars. Asian Journal of Plant Sciences. 2004; 3:20-24

Ali M. Effect of summer legumes on productivity and nitrogen economy of succeeding rice (Oriza sativa) in sequential cropping. Indian Journal of Agricultural Sciences. 1992; 62:466 467

Ali M. Weed suppressing ability and productivity of short duration legumes with pigeonpea under rainfed condition. Tropical Pest Management. 1988; 34:384-387

Ashraf, M.U., Sirinives, P.E., Sadiq, M.S. and Saleem, M. (2001) AVRDC Germplasm, Its Utilization and Development of Improved Mungbean. Pakistan Journal of Botany, 33, 443-452.

Betal S, Chowdhury PR, Kundu S, Raychaudhuri SS. Estimation of genetic variability of Vigna radiata cultivar by RAPD analysis. Biologia Plantarum. 2004; 48:205-209

Bhadra SK. Inheritance of nine-foliate leaf in mungbean (Vigna radiata (L.) Wilczek). SABRAO Journal. 1991; 23:71-73

Bose RD. Studies in Indian pulses. IX. Contributions to the genetics of mung (Phaseolus radiaus L.). Indian Journal of Agricultural Sciences. 1939; 9:575594

Chaitieng B, Kaga A, Han OK, Wang KW, Wongkaew S, Laosuwan $\mathrm{P}$, et al., Mapping a new source of resistance to powdery mildew in mungbean. Plant Breeding. 2002; 121:521-525

Chankaew, S., Isemura, T., Naito, K., OgisoTanaka, E., Tomooka, N., Somta, P., et al., (2014) QTL Mapping for Salt Tolerance and Domestication-Related Traits in Vigna marina Subsp. oblonga, a Halophytic Species. Theoretical and Applied Ge-netics, 127, 691-702.

Chankaew, S., Somta, P., Sorajjapinun, W., \&Srinives, P. (2011). Quantitative trait loci mapping of Cercospora leaf spot 
resistance in mungbean, Vigna radiata (L.) Wilczek. Molecular Breeding, 28(2), 255-264.

Chhabra AK. Inheritance of lobed and pentafoliate leaf in mungbean. Indian Journal of Pulses Research. 1990; 3:6972

Dwivedi S, Singh DP. Inheritance of fasciation in mungbean (Vigna radiata L. Wilczek). Indian Journal of Genetics \& Plant Breeding. 1990; 50:81-82

Dwivedi S, Singh DR. Inheritance of narrow trifoliate leaf in mungbean (Vigna radiata (L.) Wilczek). SABRA Journal. $1985 ; 17: 177-180$

Fatokun CA, Menancio-Hautea D, Danesh D, Young ND. Evidence for orthologous seed weight genes in cowpea and mungbean based on RFLP mapping. Genetics. 1992; 132:841-846

Ghat KV, Lakhanpaul S, Chadha S. Amplified fragment length polymorphism (AFLP) analysis of genetic diversity in Indian mungbean (Vigna radiata (L.) Wilczek) cultivars. Indian Journal of Biotechnology. 2005; 4:56-64

Humphry ME, Lambrides CJ, Chapman SC, Aitken EAB, Imrie BC, Lawn RL, et al., Relationships between hard seededness and seed weight in mungbean (Vigna radiata) assessed by QTL analysis. Plant Breeding. 2005; 124:292-298

Isemura, T., Kaga, A., Tabata, S., Somta, P., Srinives, P., Shimizu, T., \&Tomooka, N. (2012). Construction of a genetic linkage map and genetic analysis of domestication related traits in mungbean (Vigna radiata). PLoS one, $7(8)$.

Kaewwongwal, A., Chen, J., Somta, P., Kongjaimun, A., Yimram, T., Chen, X., et al., (2017) Novel Alleles of Two Tightly Linked Genes Encoding Polygalacturo-nase-Inhibiting Proteins
(VrPGIP1 and VrPGIP2) Associated with the Br Locus that Confer Bruchid (Callosobruchus spp.) Resistance to Mungbean (Vigna radiata) Accession V2709. Frontiers in Plant Sciences, 8, 1692.

Khattak GSS, Ashraf M, Haq MA, Srinives P. Genetic architecture of seed yield and yield components in mungbean [Vigna radiata (L.) Wilczek]. Tropical Agriculture. 2002; 79:260-264

Lambrides CJ. Breeding for improved seed quality traits in mungbean (Vigna radiata L. Wilczek) using DNA markers [Ph.D. Thesis]. Australia Lambrides CJ: University of Queensland; 1996

Lambrides, C.J. and Imrie, B.C. (2000) Susceptibility of Mungbean Varieties to the Bruchid Species Callosobruchus maculatus (F.), C. phaseoli (Gyll.), C. chinensis (L.), and Acanthoscelides obtectus (Say.) (Coleoptera: Chrysomelidae). Australian Journal of Agricultural Research, 51, 85-90.

Mathivathana, M. K., Murukarthick, J., Karthikeyan, A., Jang, W., Dhasarathan, M., Jagadeeshselvam, N., \& Raveendran, M. (2019). Detection of QTLs associated with Mungbean Yellow Mosaic Virus (MYMV) resistance using the interspecific cross of Vigna radiata $\times$ Vigna umbellata. Journal of applied genetics, 60(3-4), 255-268.

Mehandi S, Singh IP, Bohra A, Singh CM. (Supplement on Genetics \& Plant Breeding) Estimates of genetic variability and heritability for yield and yield component traits in mungbean [Vigna radiata (L.) Wilczek]. The Bioscan. 2013; 8(4): 00-00

Mehandi, S., Quatadah, S. M., Mishra, S. P., Singh, I. P., Praveen, N., \&Dwivedi, N. (2019). Mungbean (Vigna radiata L. Wilczek): Retrospect and Prospects. In 
Legume Crops-Characterization and Breeding for Improved Food Security. IntechOpen.

Mishra RC, Sahu RC, Tripathi D. Inheritance of hypocotyl color in green gram (Phaseolus aureus Roxb). Indian Science Congress Association Proceedings. 1970; 57:290

Murty BK, Patel GJ. Inheritance of seed coat colour in green gram. Indian Journal of Genetics \& Plant Breeding. 1972; 32:373-378

Nair, R.M., Götz, M., Winter, S., Giri, R.R., Boddepalli, V.N., Sirari, A., et al., (2017) Identification of Mungbean Lines with Tolerance or Resistance to Yellow Mosaic in Fields in India where Different Begomovirus Species and Different Bemisia tabaci Cryptic Species Predominate. European Journal of Plant Pathology, 149, 349-365.

Nair, R.M., Yang, R.Y., Easdown, W.J., Thavarajah, D., Thavarajah, P., d'A Hughes, J., et al., (2013) Biofortification of Mungbean (Vigna radiata) as a Whole Food to Enhance Human Health. Journal of the Science of Food and Agriculture, 93, 18051813.

Pande K, Raghuvanshi SS. Gamma rays induced high yielding dwarf mutant in V. radiata L. Wilczek. Mutation Breeding Newsletter. 1988; 32:6-7

Pathak H, Singh S. Inheritance studies in green gram. Indian Journal of Genetics \& Plant Breeding. 1963; 23:215-218

Poolsawat, O., Kativat, C., Arsakit, K. and Tantasawat, P.A. (2017) Identification of Quantitative Trait Loci Associated with Powdery Mildew Resistance in Mungbean Using ISSR and ISSR-RGA Markers. Molecular Breeding, 37, 150.

Rachie KO, Roberts LM. Grain legumes of lowland tropics. Advances in Agronomy. 1974; 26:1-132

Rheenen V. The inheritance of some characters in the mungbean, Phaseolus aureus Roxb. Genetica. 1965; 36:412419

Sahli AD, Das K. Studies on growth and yield of three mungbean (Vigna radiata $\mathrm{L}$. Wilczek) cultivars. Indian Journal of Plant Physiology. 1979; 22:147-154

Saini A, Reddy SK, Jawali N. Evaluation of long primers for AP-PCR analysis of mungbean (Vigna radiata (L.) Wilczek): Genetic relationships and fingerprinting of some genotypes. Indian Journal of Biotechnology. 2004; 3:511-518

Saini RG, Minocha JL, Singh A. Sterile mutants in Phaseolus aureus. Science and Culture. 1974; 40:37-38

Sareen PK. Further genetic analysis of the trilobate leaf mutants in mungbean (Vigna radiata var. aureus (L.) Wilczek). Current Science. 1985; 54:930-931

Schafleitner, R., Huang, S.M., Chu, S.H., Yen, J.Y., Lin, C.Y., Yan, M.R., et al., (2016) Identification of Single Nucleotide Polymorphism Markers Associated with Resistance to Bruchids (Callosobruchus spp.) in Wild Mungbean (Vigna radiata var. sublobata) and Cultivated $V$. radiata through Genotyping by Sequencing and Quantitative Trait Locus Analysis. BMC Plant Biology, 16, 159.

Siddique M, Malik MFA, Shahid IA. Genetic divergence, association and performance evaluation of different genotypes of mungbean. International Journal of Agriculture and Biology. 2006; 8(6):793-795

Singh BB, Singh DP. Prospects of creating higher yield potential in chickpea. In: Asthana AN, Ali M, editors. Recent Advances in Pulses Research. Kanpur, India: Indian Society of Pulses Research and Development; 1995. pp. 65-88

Singh P, Singh IB, Singh U, Singh HG. 
Interspecific hybridization between mung (Phaseolus aureus Roxb.) and urd (Phaseolus mungo L.). Science and Culture. 1975; 41:233-234

Singh, N., Mallick, J., Sagolsem, D., Mandal, N. and Bhattacharyya, S. (2017) Mapping of Molecular Markers Linked with MYMIV and Yield Attributing Traits in Mungbean. Indian Journal of Genetics and Plant Breeding, 78, 118-126.

Sinha RR, Das K, Sen SK. DNA markers in mungbean. India Embryoids from mesophyll protoplast of Vigna mungo (L) Hepper: A seed legume crop plant [Ph.D. Thesis]. Vol. 22. University of Mumbai; Basic Life Sciences. 2003. pp. 209-211

Talukdar T, Talukdar D. Inheritance of growth habbit and leaf shape in mungbean [Vigna radiata (L.)
Wilczek]. Indian Journal of Genetica\& Plant Breeding. 2003; 63:165-166

Thakare et al., Green cotyledons mutant in mungbean [Vigna radiata (L.)Wilczek]. Current Science. 1980; 49:945-946

Tsou CS, I Isu MS, Tan ST, Park HG. Protein quality of mungbean and its improvement. AitoHorticulturac. 1979; 93:279-289

Verma P. Inheritance of photosensetivity in mungbean (Phaseolus aureus Roxb.). Mysore Journal of Agricultural Sciences. 1971; 5:477-480

Wati, L. (2017) Screening of Rhizobial Isolates from Vigna radiata for Plant Growth Promoting Traits. Research on Crops, 18, 190-195.

Watt EE, Marechal R. The differences between mung and urd beans. Tropical Grain Legume Bulletin. 1977; 7: 31-33.

\section{How to cite this article:}

Jyoti Prakash Sahoo, Ambika Prasad Mishra, Deviprasad Mishra and Kailash Chandra Samal. 2020. Nutrient-Rich Beans with Benefit (Vigna radiata (L.) Wilczek): A Review. Int.J.Curr.Microbiol.App.Sci. 9(08): 3280-3289. doi: https://doi.org/10.20546/ijcmas.2020.908.375 